\title{
ANALISIS KeBUTUHAN PENGEMBANGAN BUKU AJAR KOMPREHENSI LISAN BERBASIS NILAI-NILAI ISLAM DAN BERORIENTASI LITERASI DIGITAL
}

\author{
PURWATI ZISCA DIANA', DENIK WIRAWATI ${ }^{2}$ \\ Pendidikan Bahasa dan Sastra Indonesia Fakultas Keguruan dan Ilmu Pendidikan \\ Universitas Ahmad Dahlan Yogyakarta \\ Corresponding author: 'purwati.diana@pbsi.uad.ac.id.
}

Pertama Diterima: 8 Oktober 2020

Bukti Akhir Diterima: 30 Desember 2020

\begin{abstract}
Abstrak
Bahan ajar diperlukan pada setiap mata kuliah sebagai penunjang kegiatan belajar bagi mahasiswa. Hal tersebut juga berlaku untuk mata kuliah Komprehensi Lisan. Pada tahap awal, perlu diketahui analisis kebutuhan terhadap penyusunan buku ajar Komprehensi Lisan. Buku ajar komprehensi lisan ini memiliki ciri khusus, yaitu berbasis nila -nilai Islam dan berorientasi literasi digital. Analisis kebutuhan ini merupakan dari penelitian dan pengembangan (R\&D). Metode yang digunakan dalam penelitian ini adalah penelitian survei. Pengumpulan data dilakukan dengan wawancara, observasi pembelajaran, dan pengisian angket terkait respons mahasiswa dan dosen pengampu dalam pembelajaran Komprehensi Lisan. Data yang diperoleh dalam bentuk kualitatif dan kuantitatif. Data kualitatif dianalisis secara deskriptif dan data kuantitatif dianalisis secara deskriptif dengan presentase. Hasil analisis kebutuhan ini, menunjukkan bahwa mahasiswa membutuhkan buku ajar komprehensi lisan yang mudah dipahami, mengintegrasikan nilai-nilai Islam, dan terdapat contoh audio visual yang dikemas dalam teknologi digital. Berdasarkan hasil penelitian tersebut dapat disimpulkan bahwa perlu dikembangkan buku ajar komprehensi lisan yang berbasis nilainilai Islam dan berorientasi literasi digital untuk memfasilitasi mahasiswa dalam belajar, baik bersama pendidik maupun secara mandiri.
\end{abstract}

Kata kunci: analisis kebutuhan, komprehensi lisan, nilai-nilai Islam, literasi digital

\begin{abstract}
Teaching materials are needed in each subject to support learning activities for students. This also applies to the Oral Comprehension course. At the initial stage, it is necessary to know the needs analysis for the preparation of the Oral Comprehension textbook. This oral comprehensive textbook has special characteristics, namely based on Islamic values and digital literacy oriented. This needs analysis is from research and development $(R \& D)$. The method used in this research is survey research. Data collection was carried out by interviewing, observing learning, and filling out questionnaires related to the responses of students and lecturers in Oral Comprehension learning. The data obtained were in qualitative and quantitative form. Qualitative data were analyzed descriptively and quantitative data were analyzed descriptively by percentage. The results of this needs analysis show that students need oral comprehensive textbooks that are easy to understand, integrate Islamic values, and there are audiovisual examples packaged in digital technology. Based on the results of this study, it can be concluded that it is necessary to develop oral comprehensive textbooks based on Islamic values and digital literacy oriented to facilitate students in learning, both with educators and independently.
\end{abstract}

Keywords: needs analysis, oral comprehension, Islamic values, digital literacy

\section{PENDAHULUAN}

Menyimak (listening) berbeda dengan mendengar (hearing). Menyimak bersifat aktif, sedangkan mendengar bersifat pasif, spontan, dan tidak selektif. Menyimak tidak hanya merupakan aktivitas mendengarkan tetapi merupakan sebuah proses memilih dari sekian banyak rangsangan di 
lingkungan sekitar. Menurut Underwood (1997: 2) menyimak merupakan kegiatan mendengarkan atau memperhatikan baik-baik apa yang diucapkan orang, menangkap dan memahami makna dari apa yang didengar. Menyimak menyangkut proses dan interpretasi terhadap informasi yang diterima. Menyimak merupakan salah satu bagian penting dalam proses komunikasi sehingga tetap harus dipelajari dan dilatih. Bahkan menyimak dapat diklasifikasikan sebagai sebuah seni bergaul atau keterampilan berkomunikasi. Pentingnya peranan menyimak dalam proses komunikasi bukan saja karena memiliki manfaat dalam mengembangkan kemampuan komunikasi, tetapi juga karena menyimak menempati ruang paling besar dalam aktivitas komunikasi.

Dalam penelitian ini untuk keterampilan menyimak digunakan istilah komprehensi lisan. Hal tersebut disesuaikan dengan nama salah satu mata kuliah keterampilan di Program Studi Pendidikan Bahasa dan Sastra Indonesia. Makna kata komprehensi menurut KBBI edisi V daring adalah mampu menangkap (menerima) dengan baik. Adapun makna komprehensi lisan adalah menangkap (menerima) dengan baik pesan lisan.

Menurut Saddhono \& St. Y. Slamet (2014: 15) dalam peristiwa menyimak ada tiga faktor yang dominan. Pertama, faktor kesengajaan tampak dengan jelas dan nyata. Kedua, faktor pemahaman harus ada dan tampak pula dengan jelas. Ketiga, faktor penilaian dapat muncul dengan nyata pula. Kelengkapan faktor-faktor inilah yang membuat menyimak tinggi tarafnya dari mendengarkan maupun mendengar.

Kegiatan menyimak tidak dapat terlepas dari kegiatan manusia sehari-hari. Pesatnya perkembangan teknologi pun berpengaruh pada pemaknaan pesan yang dikomunikasikan. Tingkat melek teknologi juga membawa perubahan pada proses menyimak informasi dengan cepat melalui berbagai media. Perkembangan teknologi informasi saat ini dikembangkan secara maksimal di berbagai jenjang pendidikan dalam menghasilkan manusia kreatif, cerdas, dan inovatif (Momang, 2019: 1). Mahasiswa Pendidikan Bahasa dan Sastra Indonesia dituntut untuk memiliki pemahaman dalam keterampilan menyimak atau komprehensi lisan sebagai bekal dalam kehidupan di masyarakat.

Dinamika perkuliahan di kelas merupakan pengalaman dan kegiatan mahasiswa yang bermakna dan dapat menjadi tantangan bagi setiap dosen untuk menemukan keseimbangan antara apa yang berarti bagi mahasiswa dan tujuan yang sesuai dengan kehidupan mereka. Dalam rangka membekali mahasiswa melalui mata kuliah komprehensi lisan terdapat berbagai upaya yang dilakukan. Salah satunya bahan ajar komprehensi lisan yang sesuai dengan kebutuhan mahasiswa, yang tercantum dalam Rencana Pembelajaran Semester (RPS). Dalam hal ini, bahan ajar yang dapat digunakan mahasiswa untuk mendukung perkuliahan komprehensi lisan berupa buku ajar.

Selama ini perkuliahan Komprehensi Lisan menggunakan buku Menyimak: Sebagai Suatu Keterampilan Berbahasa karya Henry Guntur Tarigan sebagai acuan sumber referensi utama. Sementara, dalam pembelajaran komprehensi lisan di Program Studi Pendidikan Bahasa dan Sastra Indonesia, Fakultas Keguruan dan Ilmu Pendidikan, Universitas Ahmad Dahlan Yogyakarta belum menggunakan buku acuan yang menjadi sumber belajar mahasiswa. Mahasiswa hanya menerima materi yang dipaparkan dosen dan temannya saat presentasi di kelas. Media yang digunakan pun cenderung menggunakan video simakan. Hasilnya, kompetensi mahasiswa terbatas pada tingkat memahami kajian teoretis menyimak. 
Buku ajar adalah buku yang ditulis dengan tujuan utama sebagai sumber acuan pembelajaran yang mencakup bidang ilmu tertentu dengan memenuhi kaidah penulisan karya ilmiah yang diterbitkan dan disebarluaskan (Arifin, 2009: 58). Pandangan lain mengenai buku ajar juga disampaikan (Obrazovni, 2009: 16) bahwa buku ajar merupakan alat dalam mengajar yang disusun berdasarkan kurikulum. (Tomlinson, 2008: 3) mengemukakan bahwa buku ajar yang tidak sesuai dengan proses pembelajaran dapat menyebabkan gagalnya pembelajaran.

Pendidikan tidak dapat dipahami secara terbatas hanya kepada pengajaran. Keberhasilan pendidikan bagi anak-anak tidak cukup diukur hanya dari segi penguasaan kognitif atau pengetahuan tentang suatu masalah. Menurut Majid \& Andayani (2012: 95) justru yang lebih penting bagi umat Islam, berdasarkan ajaran kitab suci dan sunnah ialah penanaman nilai-nilai kemanusiaan dalam wujud nyata, seperti tingkah laku dan budi pekerti sehari-hari akan melahirkan budi luhur atau al-akhlaq al-karimah. Nilai-nilai insaniyah yang perlu ditanamkan dalam pendidikan, meliputi: sillat al-rahmi, al-ukhuwah, al-musawah, al-'adalah, husnu al-dzan, al-tawadlu, al-wafa, insyirah, al-amanah, iffah atau ta'affuf, qawamiyah, dan al-munfiqun.

Secara tradisional, literasi dipandang sebagai kemampuan membaca dan menulis. Orang dapat dikatakan literat dalam pandangan ini adalah orang yang mampu membaca dan menulis atau bebas buta huruf. Pengertian literasi selanjutnya berkembang menjadi kemampuan membaca, menulis, berbicara, dan menyimak. Saat ini definisi literasi telah bergeser dari pengertian yang sempit menuju pengertian yang lebih luas mencakup berbagai bidang penting lainnya. Perubahan ini disebabkan oleh berbagai faktor, baik faktor perluasan makna akibat semakin luas penggunaannya, perkembangan teknologi informasi dan komunikasi, maupun perubahan analogi.

Menurut Abidin, Mulyati, \& Yunansah (2017: 1) literasi didefinisikan sebagai kemampuan untuk menggunakan bahasa dan gambar dalam bentuk yang kaya dan beragam untuk membaca, menulis, mendengarkan, berbicara, melihat, menyajikan, dan berpikir kritis tentang ide-ide. Literasi berfungsi untuk menghubungkan individu dan masyarakat, serta merupakan alat penting bagi individu untuk tumbuh dan berpartisipasi aktif dalam masyarakat yang demokratis.

Era kehidupan sekarang ini populer dengan istilah era reformasi dan globalisasi. Dalam memasuki akhir abad ke-20 ini, para pakar menyebutnya telah terjadi eksplosif informasi (Darmawan, 2016: 4). Fakta ini menuntut kemampuan, pengetahuan, dan kearifan pendidik (guru/dosen) untuk memilih dan memilah informasi yang benar-benar bermanfaat bagi kepentingan proses pembelajaran.

Teknologi, pada hakikatnya memudahkan manusia dalam melakukan apapun untuk meningkatkan produktivitasnya (Prawiradilaga, Ariani, \& Handoko, 2016: 70). Dalam bidang pendidikan, sejak hadirnya era informasi, mengalami banyak perubahan. Dampak yang cukup besar adalah pada perubahan paradigma, dari orientasi pada guru atau dosen (teacher-centered) menjadi berorientasi pada pada mahasiswa sebagai peserta didik (student-centered). Pola blended learning atau hybrid learning, pola yang mengombinasikan pembelajaran tatap muka (face to face) dan pembelajaran daring (online learning), lebih banyak digunakan di Indonesia.

Berdasarkan uraian tersebut penelitian ini didasari oleh adanya masalah dan urgensi kebutuhan yang diperoleh melalui observasi, analisis dokumen, wawancara, dan pengisian angket. Penelitian ini bertujuan untuk mengetahui hasil dari analisis kebutuhan dalam mengembangkan 
buku ajar mata kuliah Komprehensi Lisan yang berbasis nilai-nilai Islam dan berorientasi literasi digital. Manfaat dalam penelitian ini untuk menambah referensi buku ajar bagi mahasiswa yang dapat digunakan untuk mempermudah mempelajari mata kuliah Komprehensi Lisan dan mencapai tujuan dalam bidang keterampilan komprehensi lisan.

\section{METODE PENELITIAN}

Penelitian ini merupakan penelitian pengembangan yang menghasilkan produk dan menguji keefektifan produk tersebut (Sugiyono, 2012: 297). Menurut Gall, Gall \& Borg ada sepuluh langkah penelitian dan pengembangan. Namun, Sukmadinata (2012: 57) memodifikasi penelitian dan pengembangan menjadi tiga langkah. Pertama, studi pendahuluan, mengkaji teori dan mengamati produk atau kegiatan yang ada. Kedua, melakukan pengembangan produk atau program kegiatan baru. Ketiga, menguji atau memvalidasi produk atau program kegiatan baru. Kegiatan pengembangan dilakukan melalui beberapa kali uji coba, dengan sampel terbatas dan sampel lebih luas. Pengujian produk dilakukan dengan melakukan eksperimen. Penelitian ini menggunakan langkah-langkah menurut Sukmadinata yang dianggap sesuai untuk tahap- tahap penelitian dan pengembangan yang akan dilakukan

Jenis penelitian yang digunakan adalah penelitian survei. Jenis penelitian ini merupakan bagian dari penelitian Research and Development (R\&D). Subjek penelitian ini adalah mahasiswa semester I pada tahun ajaran 2019/2020 yang menempuh mata kuliah Komprehensi Lisan. Kegiatan penelitian dilaksanakan di Universitas Ahmad Dahlan, Yogyakarta. Teknik pengumpulan data yang digunakan adalah observasi, analisis dokumen, wawancara, dan pengisian angket.

Proses analisis data menggunakan teknik analisis data model McDonough \& McDonough dengan kegiatan peer-debriefing. Peer-debriefing merupakan salah satu teknik untuk menguji kredibilitas temuan data penelitian yang diperoleh sebelumnya, dengan cara mengajukan pertanyaan-pertanyaan secara lebih cermat kepada narasumber/subjek penelitian yang belum pernah diteliti (Cohen et al., 2007: 108). Dalam hal ini, peneliti mewawancarai dan memberikan angket kepada mahasiswa dan dosen-dosen pengampu mata kuliah Komprehensi Lisan di Program Studi Pendidikan Bahasa dan Sastra Indonesia, Fakultas Keguruan dan Ilmu Pendidikan, Universitas Ahmad Dahlan Yogyakarta.

\section{HASIL DAN PEMBAHASAN}

Temuan pada studi pendahuluan ini mendeskripsikan tentang analisis kebutuhan buku ajar komprehensi lisan di Program Studi Pendidikan Bahasa dan Sastra Indonesia, Fakultas Keguruan dan Ilmu Pendidikan, Universitas Ahmad Dahlan Yogyakarta. Analisis kebutuhan terhadap pengembangan buku ajar Komprehensi Lisan berbasis nilai-nilai Islam dan berorientasi literasi digital diperoleh melalui penyebaran kuesioner, observasi, wawancara, dan analisis dokumen. Kuisioner digunakan untuk menemukan kebutuhan-kebutuhan mahasiswa dan dosen mengenai model produk yang dibutuhkan pada pembelajaran ini. Observasi digunakan untuk menganalisis kebutuhan melalui pengamatan langsung dalam pembelajaran Komprehensi Lisan. Wawancara digunakan untuk menemukan kebutuhan dosen pengampu dan desain produk yang dikembangkan untuk pembelajaran Komprehensi Lisan. Analisis dokumen digunakan untuk menelaah dokumen- 
dokumen yang menunjang pembelajaran atau dokumen-dokumen yang terarsip dari hasil kegiatan pembelajaran Komprehensi Lisan.

\section{Analisis Kebutuhan Mahasiswa}

Berdasarkan hasil kuesioner yang diberikan kepada mahasiswa Program Studi Pendidikan Bahasa dan Sastra Indonesia sebanyak 71\% mahasiswa menyatakan bahwa pembelajaran komprehensi lisan sangat penting untuk diajarkan dan 29\% mahasiswa menyatakan penting untuk diajarkan, dengan alasan dapat memahami teknik menyimak dengan benar. Menyimak bukan sekadar hanya dapat mendengarkan, tetapi pembelajaran komprehensi lisan (keterampilan menyimak) menjadi salah satu tolok ukur tingkat penguasaan dan kemampuan untuk berpikir.

Pada aspek sumber belajar, sebagian besar mahasiswa menggunakan buku Keterampilan Menyimak karya Prof. Dr. Henry Guntur Tarigan. Selain menggunakan buku tersebut, sumber belajar komprehensi lisan yang digunakan mahasiswa diambil dari internet (media sosial), video (youtube), dan menyimak penjelasan dari dosen. Mahasiswa berharap ada sumber belajar yang digunakan sebagai panduan dalam pembelajaran komprehensi lisan, dengan alasan buku teks Keterampilan Menyimak karya Prof. Dr. Henry Guntur Tarigan sulit dipahami oleh mahasiswa dan sumber belajar dari internet juga dianggap kurang lengkap dalam pembahasannya. Oleh karena itu, buku ajar Komprehensi Lisan sangat diharapkan oleh mahasiswa mampu menjadi sumber belajar yang mudah dipahami dan memaksimalkan pencapaian kompetensi pembelajaran Komprehensi Lisan. Bahan ajar komprehensi lisan yang diharapkan mahasiswa berupa buku ajar yang mencakup semua materi terkait komprehensi lisan, ringkasan, dan latihan soal.

Aspek materi yang diharapkan terdapat dalam buku ajar komprehensi lisan meliputi: (1) hakikat menyimak, (2) ragam menyimak, (3) menyimak efektif, (4) suasana menyimak dan daya simak, (5) proses menyimak dan memilih bahan simakan, (6) strategi dan teknik dalam pembelajaran menyimak, dan (7) contoh berupa video. Alasannya, mahasiswa memerlukan teori-teori tentang pembelajaran komprehensi lisan (keterampilan menyimak) untuk memahami wawasan pengetahuan dan mengimplementasikan baik di dalam pembelajaran kelak di kelas (untuk menjadi guru) dan dalam kehidupan sehari-hari di lingkungan masyarakat.

Dalam buku ajar komprehensi lisan, selain memuat materi-materi tentang teori keterampilan menyimak, juga dikaitkan dengan nilai-nilai Islam dan berorientasi pada literasi digital. Sesuai dengan visi Universitas Ahmad Dahlan, "Menjadi perguruan tinggi yang diakui secara internasional dan dijiwai nilai-nilai Islam", maka produk penelitian ini pun diintegrasikan dengan pembelajaran berbasis nilai-nilai Islam. Hasil penelitian menunjukkan sebanyak 87,1\% mahasiswa memahami nilai-nilai Islam dalam pendidikan dan 12,9\% tidak/belum memahami nilai-nilai Islam dalam pendidikan. Oleh karena itu, sebanyak 45,2\% mahasiswa menyatakan sangat setuju jika buku ajar komprehensi lisan (menyimak) mengintegrasikan nilai-nilai Islam, dan sebanyak 48,4\% mahasiswa menyatakan setuju, 3,2\% mahasiswa menyatakan cukup setuju, serta 3,2\% mahasiswa menyatakan tidak setuju.

Berkaitan dengan literasi digital, model buku ajar komprehensi lisan ini akan diintegrasikan dengan nilai-nilai Islam dan berorientasi literasi digital. Sebanyak 87,1\% mahasiswa telah 
memahami istilah literasi digital dan 12,9\% mahasiswa tidak/belum memahami istilah literasi digital. Berdasarkan hasil kuesioner, sebanyak 93,5\% mahasiswa selalu memanfaatkan akses internet sebagai media pembelajaran dan sumber informasi, dengan alasan bahwa dengan internet dapat memudahkan sistem belajar, sedangkan sebanyak 6,5\% mahasiswa belum terbiasa mengakses internet untuk keperluan sumber belajar. Pada era digital saat ini, mahasiswa lebih banyak memanfaatkan internet untuk mencari sumber referensi, hal tersebut dibuktikan dari hasil kuesioner yang menunjukkan sebanyak 90,3\% mahasiswa menggunakan internet untuk mencari sumber referensi.

\section{Analisis Kebutuhan Dosen}

Kajian tentang analisis kebutuhan dosen dalam penelitian tahap studi pendahuluan ini dilakukan dengan memberikan kuesioner kepada dosen pengampu mata kuliah Komprehensi Lisan. Informan ditentukan berdasarkan kecakapan dan kemahiran mereka pada bidang kajian Bahasa dan Sastra Indonesia. Selain itu, penentuan informan juga didasarkan pada kemahiran mereka dalam mengemukakan pendapatnya terkait dengan kesesuaian antara buku ajar yang digunakan selama ini dengan kebutuhan mereka pada buku ajar Mata Kuliah Komprehensi Lisan yang mereka harapkan.

Berdasarkan hasil kuesioner yang diberikan kepada dosen pengampu mata kuliah Komprehensi Lisan Program Studi Pendidikan Bahasa dan Sastra Indonesia, Fakultas Keguruan dan Ilmu Pendidikan, Universitas Ahmad Dahlan, diperoleh hasil 75\% dosen menyatakan bahwa pembelajaran komprehensi lisan sangat penting untuk diajarkan, dan 25\% dosen menyatakan pembelajaran komprehensi lisan penting untuk diajarkan. Alasannya, mata kuliah komprehensi lisan berfungsi sebagai modal dalam memahami apa disimak. Selain itu, komprehensi lisan merupakan kemampuan dasar untuk memahami keterampilan bahasa yang lainnya, seperti berbicara, membaca, dan menulis, serta memahami ilmu lainnya.

Selama ini buku yang digunakan sebagai acuan Mata Kuliah Komprehensi Lisan, berupa buku teks yang bukan ditulis oleh dosen yang bersangkutan, melainkan buku Menyimak Sebagai Suatu Keterampilan Berbahasa karya Prof. Dr. Henry Guntur Tarigan. Oleh karena itu, dalam penelitian ini terkait pengembangan buku ajar komprehensi lisan berbasis nilai-nilai Islam dan berorientasi literasi digital bertujuan untuk menunjang kebutuhan pembelajaran komprehensi lisan bagi dosen dan mahasiswa. Biasanya mahasiswa lebih senang, bangga, dan bersemangat dalam menerima perkuliahan apabila buku yang digunakan sebagai referensi adalah buku karya dosennya sendiri. Keuntungan bagi dosen, dapat menunjang karier dan eksistensi dosen tersebut.

\section{Observasi}

Kegiatan observasi dilakukan pada semester gasal tahun akademik 2019/2020. Observasi dilakukan dengan mengamati dua hal terkait perkuliahan Komprehensi Lisan, yaitu: (1) menganalisis pembelajaran, (2) menganalisis pembelajar dan konteksnya. Tujuan observasi ini untuk mengidentifikasi kebutuhan dalam pembelajaran.

Pada kegiatan observasi, digunakan lembar observasi untuk mengamati kegiatan pembelajaran 
dan sikap mahasiswa di kelas. Adapun aspek-aspek penilaian dalam lembar observasi, antara lain: aspek aktivitas pembelajaran, sikap mahasiswa, dan bahan ajar yang digunakan. Berdasarkan observasi, menunjukkan hasil bahwa terdapat empat masalah pada proses pembelajaran komprehensi lisan. Masalah-masalah yang ditemukan, antara lain (1) dosen belum menyajikan materi secara maksimal. Dosen hanya menayangkan powerpoint yang diikuti penjelasan ceramah. (2) Belum adanya buku ajar komprehensi lisan yang ditulis oleh dosen yang bersangkutan. Selama ini, buku yang digunakan sebagai referensi buku karya Prof. Dr. Henry Guntur Tarigan yang berjudul Menyimak: Sebagai Suatu Keterampilan Berbahasa. (3) belum tampak adanya literasi digital yang digunakan sebagai bagian bahan ajar komprehensi lisan. (4) Belum memasukkan nilai-nilai Islam dalam bahan ajar komprehensi lisan sebagai penguat pribadi yang berakhlak.

Selain itu, pada aspek sikap mahasiswa, masih terdapat beberapa mahasiswa yang sibuk sendiri dengan telepon genggamnya ketika dosen memberikan penjelasan. Mahasiswa juga kurang termotivasi dengan penjelasan dosen yang sifatnya teoretis. Mahasiswa lebih antusias ketika mereka dilibatkan dalam proses pembelajaran secara aktif. Mahasiswa juga antusias dalam menyimak bahan simakan yang berupa video audiovisual.

Bahan ajar yang digunakan dalam proses pembelajaran komprehensi lisan juga tidak terlepas dari observasi. Hasil pengamatan terkait bahan ajar menunjukkan bahwa proses pembelajaran komprehensi lisan lebih dominan menggunakan powerpoint dan video simakan. Buku ajar komprehensi lisan dan media berbasis teknologi lainnya belum tampak digunakan. Berdasarkan masalah-masalah yang ditemukan, ada empat hal yang dapat simpulan dalam studi pendahuluan penelitian ini. (1) Pembelajaran komprehensi lisan membutuhkan buku ajar sebagai buku pegangan dan sumber belajar dalam mencapai kompetensi yang diharapkan, serta mampu membingkai kebutuhan materi, tugas, dan penilaian. (2) Mahasiswa lebih antusia ketika pembelajaran berpusat pada mereka dan lebih menyukai bahan simakan dalam bentuk video. (3) Pembelajaran komprehensi lisan membutuhkan media pembelajaran berbasis teknologi yang mudah diakses dan digunakan baik oleh dosen maupun mahasiswa. (4) Nilai - nilai Islam perlu diintegrasikan dalam pembelajaran komprehensi lisan sebagai penguatan karakter dan akhlak.

\section{Wawancara}

Analisis kebutuhan dalam penelitian ini juga diperoleh melalui metode wawancara. Adapun wawancara dilakukan kepada dosen pengampu mata kuliah komprehensi lisan dan perwakilan beberapa mahasiswa yang mengambil mata kuliah komprehensi lisan.

1) Wawancara Dosen Pengampu

Tujuan wawancara kepada dosen pengampu mata kuliah komprehensi lisan untuk mendapatkan informasi kebutuhan mengenai produk yang dikembangkan dalam penelitian ini. Wawancara ini juga dilakukan untuk mengonfirmasi data yang diperoleh dalam kegiatan observasi.

Berdasarkan hasil wawancara dengan dosen pengampu terdapat tiga kebutuhan dalaam pembelajaran komprehensi lisan. Pertama, pada aspek materi ajar, dosen pengampu membutuhkan sajian materi yang utuh, yang dilengkapi dengan contoh/ilustrasi seperti video 
simakan. Kedua, dosen pengampu membutuhkan tugas-tugas yang mengakomodasi ketercapaian kompetensi komprehensi lisan mahasiswa. Rancangan tugas yang dibutuhkan sekiranya dapat memotivasi mahasiswa untuk meningkatkan keterampilan. Ketiga, produk buku ajar diperlukan untuk mendukung proses pembelajaran komprehensi lisan. Kebutuhan dosen pengampu mengenai buku ajar memiliki kriteria yang lengkap dan tertata dengan baik. Cakupan isi buku ajar harus sesuai dengan aturan penulisan buku ajar. Adapun cakupan isi yang diharapkan, meliputi materi secara teoretis tentang komprehensi lisan yang juga mengintegrasikan nilai-nilai Islam, serta didukung oleh kemajuan literasi digital.

2) Wawancara Mahasiswa

Tujuan wawancara dengan mahasiswa untuk menguatkan analisis kebutuhan pada studi pendahuluan penelitian ini terkait pengembangan produk buku ajar yang dihasilkan. Hasil wawancara dengan perwakilan mahawiswa menunjukkan bahwa mahasiswa membutuhkan buku ajar sebagai pendukung mata kuliah komprehensi lisan. Adapun cakupan produk buku ajar yang diharapkan, meliputi: (a) isi materi yang lengkap dan utuh sesuai dengan Rencana Pembelajaran Semester (RPS); (b) penugasan yang jelas dan dapat merangsang antusias mahasiswa, serta mengasah pengetahuan dan keterampilan mahasiswa; (c) perlu mengintegrasikan nilai-nilai Islam sesuai dengan iklim islami yang telah tertanam di institusi dan dapat menguatkan karakter serta akhlak mahasiswa; (d) menambahkan contoh/ilustrasi berupa video yang dikemas dalam teknologiberkemajuan saat ini.

\section{Analisis Dokumen}

Penelitian ini juga melakukan analisis dokumen dalam mengidentifikasi kebutuhan pembelajaran. Dokumen yang dikaji dalam penelitian ini, antara lain: 1) Rencana Pembelajaran Semester (RPS) dan 2) buku acuan atau buku referensi. Hasil analisis dokumen pada RPS menunjukkan bahwa terdapat beberapa masalah, antara lain. (1) Dalam rancangan RPS, rumusan capaian kompetensi mahasiswa tidak sampai pada kemampuan berpikir tingkat tinggi. (2) Rumusan capaian pembelajaran tidak mengarah pada realisasi keterampilan menyimak di lingkungan masyarakat. (3) Rancangan pengalaman belajar mahasiswa terbatas pada pengalaman di kelas karena tujuan pembelajaran yang dirancang hanya sebatas pada pemahaman teoretis yang diaplikasikan melalui aktivitas-aktivitas pembelajaran tanpa mendeskripsikan pengalaman belajar yang mereka terapkan dari keterampilan komprehensi lisan (menyimak) dalam masyarakat. (4) Kurangnya sumber referensi yang digunakan dalam pembelajaran komprehensi lisan. Sumber referensi yang digunakan dalam perkuliahan ini masih bergantung pada sumber lama. Hasil analisis dokumen pada buku yang digunakan dalam perkuliahan komprehensi lisan berdasarkan daftar referensi yang digunakan pada rancangan RPS. Buku yang dijadikan acuan adalah buku referensi karya Prof. Dr. Henry Guntur Tarigan yang berjudul Menyimak: Sebagai Suatu Keterampilan Berbahasa. 


\section{PENUTUP}

Berdasarkan hasil penelitian terhadap analisis kebutuhan pengembangan buku ajar Komprehensi Lisan dapat disimpulkan bahwa sangat dibutuhkan buku ajar Komprehensi Lisan berbasis nilai-nilai Islam dan berorientasi literasi digital untuk memfasilitasi belajar mahasiswa, baik bersama pendidik maupun secara mandiri. Buku ajar merupakan bahan ajar yang dikemas secara utuh dan skematis sesuai dengan Rencana Pembelajaran Semester (RPS). 


\section{DAFTAR PUSTAKA}

Abidin, Y., Mulyati, T., \& Yunansah, H. (2017). Pembelajaran Literasi. Jakarta: Bumi Aksara.

Arifin, S. dan A. K. (2009). Sukses Menulis Buku Ajar dan Referensi. Jakarta: Grasindo.

Cohen, L., Manion, L., \& Morrison, K. (2007). Research Methods in Education. London: Routledge.

Darmawan, D. (2016). Pengembangan E-Learning: Teori dan Desain (Cetakan ke). Bandung: Remaja Rosdakarya.

Majid, A., \& Andayani, D. (2012). Pendidikan Karakter Perspektif Islam (Cetakan ke). Bandung: Remaja Rosdakarya.

Momang, H. D. (2019). Pengembangan Buku Ajar Keterampilan Menyimak untuk Mahasiswa Berdasarkan Pendekatan Autentik dengan Bantuan Multimedia (Universitas Sanata Darma). Retrieved from file:///E:/BANK PROPOSAL/R\&D BUKU AJAR KOMPRE. LISAN/RE FERENSI/TESIS_PENG BUKU AJAR MENYIMAK_USD.pdf

Obrazovni. (2009). The Textbook Education. London: Continum.

Prawiradilaga, D. S., Ariani, D., \& Handoko, H. (2016). Mozaik Teknologi Pendidikan ELearning. Jakarta: Prenadamedia Group.

Saddhono, K., \& St. Y. Slamet. (2014). Pembelajaran Keterampilan Berbahasa Indonesia Teori dan Aplikasi (Cetakan ke). Yogyakarta: Graha Ilmu.

Tomlinson, B. (2008). Language Acquisition and Language learning materials. In English Language learning materials. A Critical Review (pp. 3-13). London: Continum. 